\title{
Coercion and capacity to consent
} Gwen Adshead

Address: Broadmoor Hospital Admin Building, Crowthorne, RG45 7EG, UK

from WPA Thematic Conference. Coercive Treatment in Psychiatry: A Comprehensive Review

Dresden, Germany. 6-8 June 2007

Published: 19 December 2007

BMC Psychiatry 2007, 7(Suppl I):S30 doi:10.1 186/I47I-244X-7-SI-S30

This abstract is available from: http://www.biomedcentral.com/I47I-244X/7/SI/S30

(C) 2007 Adshead; licensee BioMed Central Ltd.

What does the capacity to consent to treatment entail and what factors influence it? To date, most research has focussed on individual factors that impair capacity to consent to treatment, such as intelligence, cognitive capacity and symptoms of mental illness. In this presentation, I want to explore the social and interpersonal factors that influence capacity to consent. I discuss the complexity of individual and social interactions and discuss coercion in two forms; overt coercion such as is found in mental hospitals, and relational coercion, arising from dependency needs [1].

\section{References}

I. Adshead G: A different voice in psychiatric ethics. In Health Care Ethics and Human Values Edited by: Fulford KWM, Dickenson D, Muray TH. Oxford: Blackwell; 2002:56-62. 